\title{
A NEW SPECIES OF SYMBIOCLADIUS KIEFFER, 1925 (DIPTERA: CHIRONOMIDAE: ORTHOCLADIINAE) FROM THE EASTERN PALAEARCTIC
}

\author{
EUGENYI A. MAKARCHENKO*, MARINA A. MAKARCHENKO, \\ and TATIANA M. TIUNOVA
}

\begin{abstract}
Institute of Biology and Soil Sciences, Russian Academy of Sciences, Far East Branch, 100 let Vladivostoku Avenue, 159, Vladivostok 690022, Russia.

*Corresponding author: makarchenko@biosoil.ru
\end{abstract}

\section{ABSTRACT}

The adult male, pupa, and fourth instar larva of Symbiocladius (s. s.) villosus Makarchenko et Makarchenko, sp. n. from the Russian Far East and Japan are described and figured. Adult male of a new species separated from all known species of subgenus by presence of a pair rodshaped chitinized structures which situated above apical parts of phallapodemes, and is closely related to the Palaearctic species $S$. (s. s.) rhithrogenae and the Nearctic S. (s. s.) chattahoocheensis. S. (s. s.) villosus sp. n. can be distinguished from the first species by shape of gonostylus which expands from the base to the middle and with longer and more numerous setae. From S. (s. s.) chattahoocheensis a new species can be separated by roundish-triangular dorsal part of inferior volsellae and presence of 2 megasetae on gonostylus.

Keywords: Diptera, Chironomidae, Symbiocladius, new species, East Asia.

\section{Introduction}

Prior to the present study, the genus Symbiocladius Kieffer, 1925 included 3 species in the subgenus Symbiocladius sensu stricto - S. (S.) chattahoocheensis Caldwell (U.S.A.), S. (S.) equitans (Claassen) (U.S.A., Canada), and S. (S.) rhithrogenae (Zavřel) (Palaearctic region) - and 3 species in the subgenus Acletius Roback - S. (A.) aurifodinae Hynes (Australia), S. (A.) renatae Spies (Argentina, Chile), and S. (A.) wygodzinskyi Roback (Argentina, Chile) (Ashe and O'Connor 2012). The larvae of species in this genus occur ectoparasitically on mayfly nymphs, where they live, feed and pupate between or under the wing pads.

The type species, $S$. (S.) rhithrogenae, was thought to be distributed all across the Palaearctic region, from mainland Spain and France through central and eastern Europe (Sæther and Spies 2013) to the Russian Far East (Makarchenko and Makarchenko 2006) and Japan (Hayashi and Kobayashi 2000). However, a comparison of European material with East Asian specimens has indicated to us that in the Far East there is a previously undetected species that is closely related to but different from the other three members of Symbiocladius s. s.

Below we provide a description of the adult male, pupa, and fourth instar larva of Symbiocladius (s. s.) villosus sp. n. from the Russian Far East and Japan.

\section{Materials and Methods}

Most of the material was collected in Primorye and Khabarovsk Territories, Amur and Magadan regions and on Sakhalin Island of the Russian Far East. Rearing of adult males from the larva and pupa, and determination of mayfly nymphs inhabited by S. (s. s.) villosus sp. n., was carried out by Dr. T. M. Tiunova. Material of S. (s. s.) villosus sp. n. from Japan was collected and reared by Dr. T. Ueno, and made available to us by Dr. T. Kobayashi. For comparison with European material we used specimens of S. (s. s.) rhithrogenae (mature pupae and larval skins) collected with mayflies in the Chornohora Mountains of Ukraine by M. Kłonowska-Olejnik and R. J. Godunko; this material was used previously in the paper by Giłka et al. (2007).

The associations between larva, pupa and adult male of S. (s. s.) villosus sp. n. were obtained by individual rearing of live larvae to mature pupae in their natural habitats, and of pupae to adults. For some populations we used pharate adult males extracted from their pupal exuviae.

Larvae and pupae were collected from nymphs belonging to 9 host species of Ephemeroptera, family Heptageniidae - Cinygma lyriformis McDunnough, Ecdyonurus aspersus Kluge, Ec. joernensis Bengtsson, Epeorus ninae Kluge, Ep. pellucidus (Brodsky), Heptagenia flava (Rostock), Rhithrogena japonica Ueno, Rh. lepnevae Brodsky, and $R h$. sibirica Brodsky (Table 1 ).

The material was fixed in $70 \%$ ethanol and later mounted on slides, following the procedure outlined by Makarchenko (1985). The morphological terminology follows that of Sæther (1980).

The holotype and paratypes of the new species are deposited in the Institute of Biology and Soil Sciences, Far East Branch of the Russian Academy of Sciences, Vladivostok, Russia (IBSS FEB RAS). 
Table 1 Mayfly hosts of Symbiocladius (s. s.) villosus sp. n. in Far Eastern regions.

\begin{tabular}{|l|c|c|c|c|c|}
\hline \multirow{2}{*}{ Host species } & \multicolumn{5}{c|}{ Locality } \\
\cline { 2 - 6 } & $\begin{array}{c}\text { Sakhalin } \\
\text { Region }\end{array}$ & $\begin{array}{c}\text { Primorye } \\
\text { Territory }\end{array}$ & $\begin{array}{c}\text { Khabarovsk } \\
\text { Territory }\end{array}$ & $\begin{array}{c}\text { Magadan } \\
\text { Region }\end{array}$ & $\begin{array}{c}\text { Japan, } \\
\text { Honshu }\end{array}$ \\
\hline Cinygma lyriformis McDunnough 1933 & + & - & - & - & - \\
\hline Ecdyonurus aspersus Kluge 1980 & - & + & - & - & - \\
\hline Ec. joernensis Bengtsson 1909 & - & + & + & - & - \\
\hline Epeorus ninae Kluge 1995 & + & - & - & - & - \\
\hline Ep. pellucidus (Brodsky 1930) & + & + & + & - & - \\
\hline Heptagenia flava (Rostock 1878) & - & + & - & - & + \\
\hline Rhithrogena japonica Ueno 1928 & - & - & - & - & - \\
\hline Rh. lepnevae Brodsky 1930 & - & + & + & + & - \\
\hline Rh. sibirica Brodsky 1930 & - & + & + & - & - \\
\hline
\end{tabular}

\section{Symbiocladius villosus Makarchenko et Makarchenko, sp. $\mathbf{n}$.}

Etymology: The species epithet, villosus (Latin for hairy, woolly), refers to the pubescence on the gonostylus.

Material: Holotype: adult male, reared from larva, Russian Far East, Primorye Territory, Bol. Ussurka River, Ussuri River basin, 20.VI. 1990, leg. T. Tiunova. Paratypes. RUSSIAN FAR EAST, Primorye Territory: 7 larvae, Frolovka River, 22.X. 1988, leg. E. Makarchenko; 1 pupal exuviae, 1 larval skin, same data as holotype, 20.VI. 1990, leg. T. Tiunova; 1 pupa with larval skin, 2 larvae, same data as holotype, except 18.VI. 1990, leg. T. Tiunova; 1 pupa with larval skin, Ussuri River, 21.VII. 1991, 1 mature pupa, 20.IX. 1991, 1 male, 1 pupal exuviae, 1.VIII. 1992, leg. T. Tiunova; 2 larvae, Bikin River, 1.VIII. 1995, leg. T. Tiunova; 1 male, Samarga River, 5.VIII. 2005. Khabarovsk Territory: 3 males, Bureya River, 4.VII. 1994, leg. E. Makarchenko; 4 pupae, 4 larvae, Khoidur River, 31.VII. 1996, leg. T. Tiunova; 3 males, same data except 17.VII. 2003, leg. V. Teslenko; 1 male, Niman River, 15.VII., 2003, leg. T. Tiunova; 1 male with pupal exuviae and larval skin, 1 female with pupal exuviae, 1 pupa with larval skin. Gur River, 1.VIII. 1996, leg. T. Tiunova; 1 pupa, 3 larvae, Okhota River, 6-8.VIII. 1988, leg. T. Tiunova; 1 male with pupal exuviae, Maya River, about $1 \mathrm{~km}$ below Nel'kan Village, 5-8.VIII. 1999, leg. T. Tiunova; 2 males, Anyui River, 28.VII. 1996, leg. T. Arefina. Amur Region: 1 pupa, Amur River, 28-29. VIII. 2004, leg. T. Tiunova. Magadan Region: 2 males, Chelomdzha River, 5.VIII. 2001, 1 male, 3.IX. 2009 leg. S. Kocharina; 1 male, same data, 5.VIII. 2002, leg. E. Khamenkova; 2 larvae, Ola River, 21.VII. 2013, 1 male, 4.VIII. 2013, leg. E. Khamenkova. Sakhalin Island: 1 male, Liu- toga River in region of Vysokoie Village, 25-26.VII. 2001, leg. E. Makarchenko; 1 larva, Avgustovka River, 24.VII. 2003, leg. E. Makarchenko; 2 larvae, Leonidovka River, 25.VII. 2002, leg. V. Teslenko; 1 pupa, Uanga River, 20.VIII. 2001. JAPAN: 2 males, reared from larvae, 2 pupal exuviae, 2 larval skins, Yagi River, Sekinomiya, Yofu City, Hyogo Prefecture, 21.V.-27.V. 2007, leg. T. Ueno.

\section{Adult male $(\mathrm{n}=6)$}

Total length $3.0-4.5 \mathrm{~mm}$. Wing length $2.08-3.12 \mathrm{~mm}$. Total length/wing length 1.21-1.53. Total coloration brown, wings grayish.

Head: Eyes slightly pubescent or bare. Temporal setae (from one side) including only 0-7 postorbitals. Clypeus with $6-13$ setae. AR 1.12-2.17. Palps usually with 3 palpomeres, but 2 nd and $3 \mathrm{rd}$ palpomeres sometimes fused; in the first case lengths $(\mu \mathrm{m})$ of palpomeres 1-3: 48-84, $52-108,40-100$, in the second case lengths $(\mu \mathrm{m})$ of palpomeres 1-2: 68, 116.

Thorax: Each antepronotal lobe with 3-7 lateral setae. Acrostichals absent, dorsocentrals 4-14, prealars 4-7. Scutellum usually without setae, only one male with 3 setae on one side.

Wing: $R, R_{1}$ and $R_{4+5}$ without setae. Costal extension very short. Anal lobe roundish, protruding. Squama with 25-50 setae. Apex of $\mathrm{R}_{4+5}$ distal of apex $\mathrm{M}_{3+4}$; $\mathrm{Cul}$ straight.

Legs: $\mathrm{BR}_{1} 1.7-2.0, \mathrm{BR}_{2} 3.4-3.9, \mathrm{BR}_{3} 3.0-4.25$. Front tibia with 1 spur $44-48 \mu \mathrm{m}$ long. Middle tibia with $1-2$ spurs $36-40 \mu \mathrm{m}$ long and $24-36 \mu \mathrm{m}$ long. Hind tibia with $1-2$ spurs $72-80 \mu \mathrm{m}$ and $28-36 \mu \mathrm{m}$ long. Hind tibia without comb but with apical group of 12-13 spinules. Lengths and proportions of leg segments as in Table 2.

Table 2 Lengths (in $\mu \mathrm{m}$ ) and proportions of leg segments in Symbiocladius (s. s.) villosus sp. $n$., male $(n=6)$.

\begin{tabular}{ccccccccccc}
\hline & $\mathbf{f e}$ & $\mathbf{t i}$ & $\mathbf{t a}_{\mathbf{1}}$ & $\mathbf{t a}_{\mathbf{2}}$ & $\mathbf{t a}_{\mathbf{3}}$ & $\mathbf{t a}_{\mathbf{4}}$ & $\mathbf{t a}_{\mathbf{5}}$ & $\mathbf{L R}$ & $\mathbf{B V}$ & $\mathbf{S V}$ \\
\hline $\mathbf{P}_{\mathbf{1}}$ & $704-976$ & $896-1248$ & $720-944$ & $400-704$ & $320-551$ & $160-184$ & $135-144$ & $0.60-0.76$ & $2.02-2.27$ & $2.26-2.56$ \\
$\mathbf{P}_{\mathbf{2}}$ & $800-1184$ & $848-1264$ & $432-672$ & $320-512$ & $216-336$ & $112-176$ & $112-144$ & $0.46-0.53$ & $2.57-2.71$ & $3.64-3.93$ \\
$\mathbf{P}_{\mathbf{3}}$ & $816-1232$ & $976-1328$ & $464-784$ & $352-528$ & $288-384$ & $128-160$ & $112-144$ & $0.46-0.59$ & $2.66-2.84$ & $3.26-3.86$ \\
\hline
\end{tabular}

European Journal of Environmental Sciences, Vol. 5, №. 1 
Hypopygium (Figs. 1a-d): Tergite IX without setae and anal point. Laterosternite IX with 7-11 setae. Transverse sternapodeme reduced. Virga absent but above apical parts of phallapodemes a pair of rod-shaped chitinized structures are situated (Fig. 1c). Gonocoxite 312$380 \mu \mathrm{m}$ long, with large roundish-triangular dorsal lobe covered by some setae and with ventral rounded protrusion of inner edge in middle part. Gonostylus 140-180 $\mu \mathrm{m}$ long, with numerous setae and, from the base to the middle, with 2 light-colored megasetae 12-24 $\mu \mathrm{m}$ long and about $4 \mu \mathrm{m}$ wide. From numerous specimens in our material only one male from Bol. Ussurka River had gonostylus with 1 megaseta.

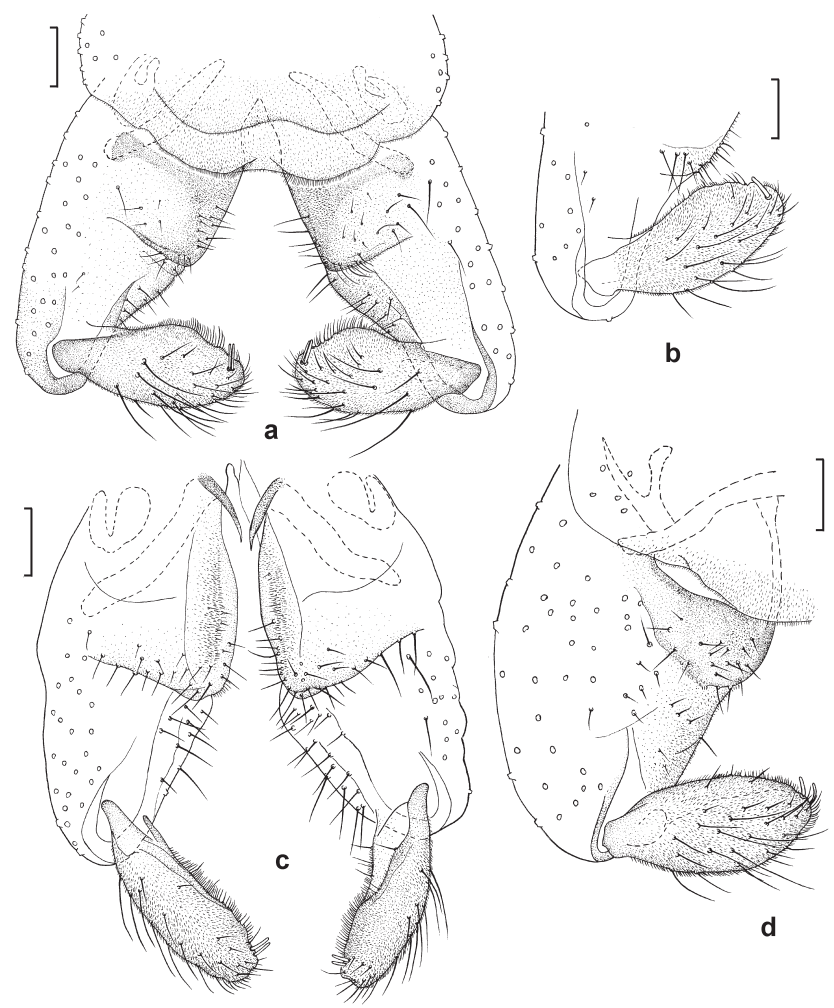

Fig. 1 Male adult of Symbiocladius (s. str.) villosus sp. n. a, d, hypopygium in dorsal view; b, gonostylus; $c$, hypopygium in dorsal view without tergite IX (extracted from mature pupa). Scale bars $50 \mu \mathrm{m}$.

Pupa $(\mathrm{n}=4)$

Total length 3.3-4.5 mm.

Cephalothorax: Light brown, with darker spots in the wing sheath area. Frontal apotome smooth, without setae or tubercles. Medial edge of antennal pedicel sheath with a spine. Thoracic horn and precorneals absent. Antepronotal area with 5 weak setae (Fig. 2c). Dorsocentrals hair-like, 8-20 $\mu \mathrm{m}$ long; distance between $\mathrm{Dcl}$ and $\mathrm{Dc}_{2}$ 12-60 $\mu \mathrm{m}$; distance between Dc2 and Dc3 26-66 $\mu \mathrm{m}$; distance between Dc3 and Dc4 12-70 $\mu \mathrm{m}$.

Abdomen: Tergites light brown. Tergites I-II without shagreen. Tergites III-V with two bands of spinules in posterior part, spinules in the more posterior band with apices directed forward (Fig. 2d). Tergites VI-VIII with one band of spinules in posterior part, their apices pointing rearward; anterior halves of tergites with very weak and fine shagreen, more intensive on tergite VIII. Segment I with 2-3 pairs of lateral setae. Segments II-VII with 3 pairs of lateral setae situated in middle part of lateral edge. Segment VIII with 1-2 pairs of lateral setae. PSA, PSB and apophyses absent. Anal lobe 224-328 $\mu \mathrm{m}$ long, without fringe and anal macrosetae but with 2-3 pairs of very short setae. Male genital sac overreaching anal lobe by $144-172 \mu \mathrm{m}$ (Fig. 2e).

\section{Fourth instar larva $(\mathrm{n}=5)$}

Total length $2.8-4.8 \mathrm{~mm}$.

Head: Head capsule $160-300 \mu \mathrm{m}$ long and $180-250 \mu \mathrm{m}$ wide; light yellow, postoccipital margin brown, interrupted in two places. Labral setae simple and very weak (Fig. 3a); premandible almost completely reduced. Antenna with 5 segments; total length $15-20 \mu \mathrm{m}$; basal segment length 5.0-6.7 $\mu \mathrm{m}$; AR 0.50-0.66; antennal seta shorter than segments 2-5 combined (Fig. 3f). Mandible 38-54 $\mu \mathrm{m}$ long, brownish, with strong apical tooth, 1 large basal inner tooth and 3 thin and spine-like inner teeth, sometimes one spine-like tooth is poorly visible; seta subdentalis and seta interna absent (Figs. 3d,e). Middle part of mentum concave, without median teeth, only with lateral convexities and 4 pairs of lateral teeth which sometimes invisible because situated under ventromental plates; setae submenti bifurcate (Figs. 3b,c).

Abdomen: Procercus absent and 5-7 setae sit on body in as a beam. Supraanal setae 100-120 $\mu \mathrm{m}$ long. Posterior parapods short and separated, on top with a hook arranged in a circle; number of hooks 27-33.

\section{Diagnosis}

Adult male of S. (s. s.) villosus sp. n. is separated from all known species of subgenus by presence of a pair rodshaped chitinized structures which situated above apical parts of phallapodemes (Fig. 1c). A new species is most closely related to the Palaearctic species $S$. (s. s.) rhithrogenae and the Nearctic S. (s. s.) chattahoocheensis and can be distinguished from the first species by shape of gonostylus which expands from the base to the middle and with longer and more numerous setae; in $S$. (s. s.) rhithrogenae gonostylus with shorter and not so numerous setae and more straight and narrow, without expansion in the middle part (Figs. 2a,b). Shape of gonostylus of $S$. (s. s.) chattahoocheensis almost the same as $S$. (s. s.) villosus sp. n. if to compare hypopygium of both species extracted from mature pupae, but shape of inferior volsellae of these species and number of megasetae on gonostylus are different, namely a new species with roundish-triangular dorsal part of inferior volsellae and 2 megasetae, $S$. (s. s.) chattahoocheensis with roundish dorsal part of inferior volsellae and 1 megaseta. It should be noted that the transverse sternaposdeme in species listed above is reduced. Data on this feature in $S$. (S.) equitans absent. The pupa of S. (s. s.) villosus sp. n. is close related to $S$. (s. s.) rhithrogenae and cannot be distinguished from latter. Both these 
species have tergites III-V with two bands of spinules in posterior part. But they are well differ from pupae of $S$. (s. s.) chattahoocheensis and $S$. (s. s.) equitans, which have two transverse bands of spinules on tergites IV-V (Claassen 1922; Caldwell 1984). To do this carry out additional research of pupae listed species. The larvae of all known species of Symbiocladius are not so well studied for a good comparison of their features, but nevertheless larvae of a new species may be separated from those of $S$. (s. s.) rhithrogenae by following characters: length of head capsule is $160-300 \mu \mathrm{m}$, width $-180-250 \mu \mathrm{m}$; mandible with 3 inner teeth; mentum with 4 pairs of lateral teeth. According to Schmid (1993) and our data larvae of S. (s. s.) rhithrogenae with head capsule 275-339 $\mu \mathrm{m}$ long and 284-351 $\mu \mathrm{m}$ wide; mandible with 4 inner teeth; mentum with 5 pairs of lateral teeth.

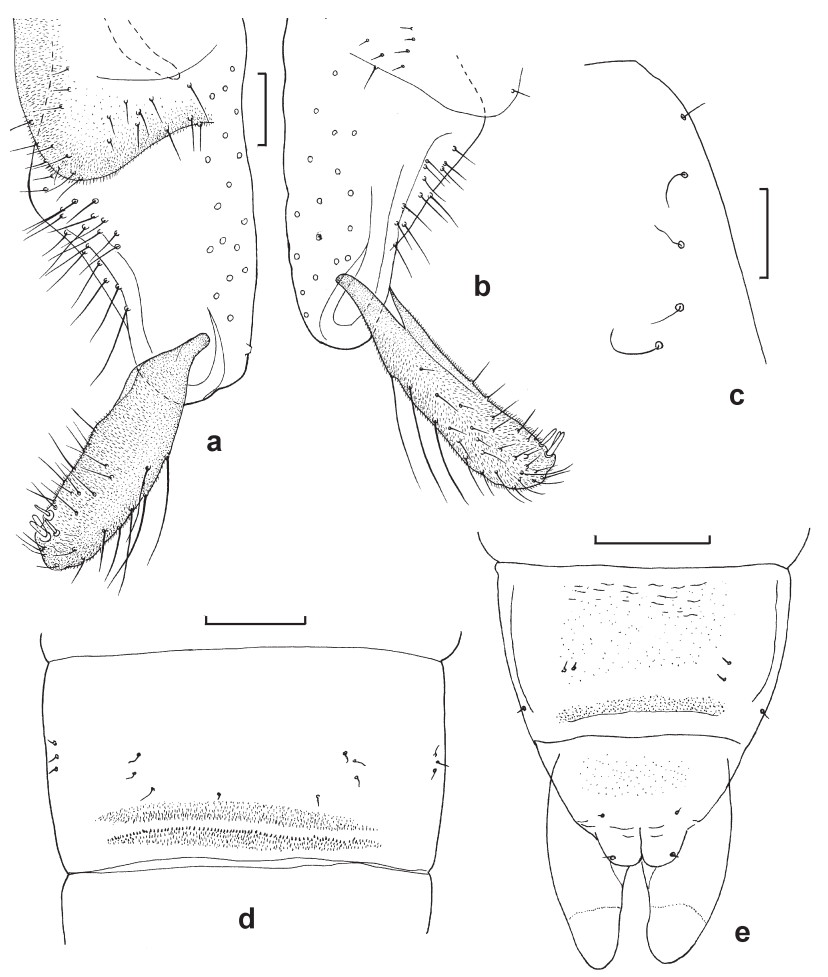

Fig. 2 Male adult of Symbiocladius (s. str.) rhithrogenae (Zavřel) (a-b), and pupa of S. (s. str.) villosus sp. n.(c-e).a-b, gonocoxite and gonostylus; c, setae of antepronotal area; d, tergite V; e, tergites VIII-IX and anal lobes. Scale bars: Figs. 5-7 - $50 \mu \mathrm{m}$; Figs. 8-9 - $200 \mu \mathrm{m}$.

\section{Remarks}

In this paper, we did not plan the revision of all species the Symbiocladius s. s. and amend or add of some characters in subgeneric diagnosis, but in the process of studying we noticed a discrepancy between some features of adults, pupae and larvae as a new species and previously known from the data given in the diagnosis of the genus, are published in the "Chironomidae of the Holarctic region" (Cranston et al. 1983, 1989; Coffman et al. 1986; Andersen et al. 2013). Work on the preparation of a diagnosis for subgenera and genus can be done and should be done in the future only after the taxonomic revision of both subgenera of Symbiocladius.

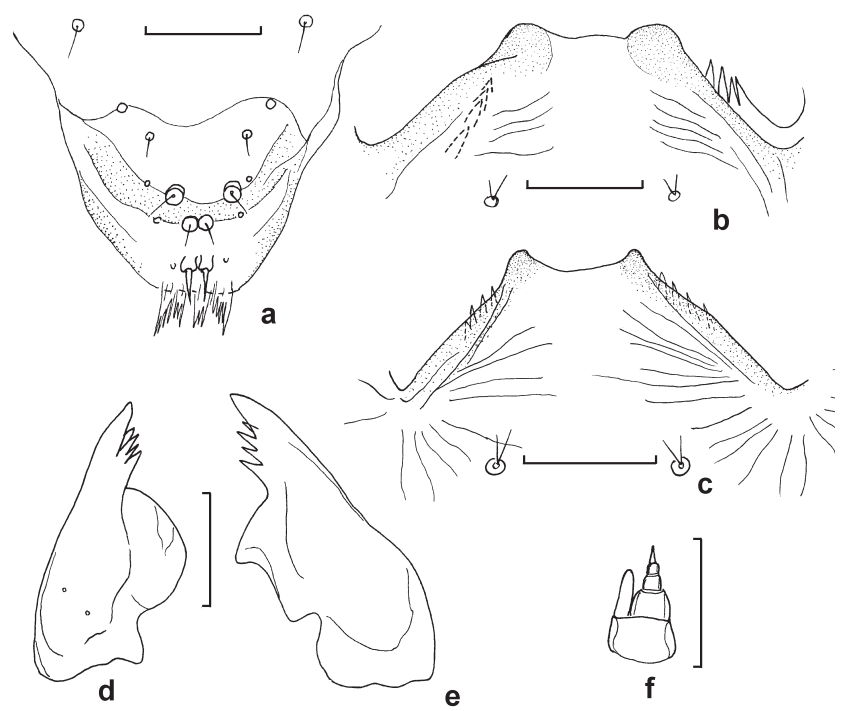

Fig. 3 Fourth instar larva of Symbiocladius (s. str.) villosus sp. n. a, labrum; b-c, mentum; d-e, mandible; f, antenna. Scale bars $20 \mu \mathrm{m}$.

Some authors interpreted the large basal inner tooth on the larval mandible as a seta subdentalis (e.g., Andersen et al. 2013: 260). However, in Symbiocladius the structure in question here does not show anything like the typical base from which true setae always arise. Therefore, we support the position of Caldwell (1984), who did not interpret the large basal inner tooth as a seta subdentalis.

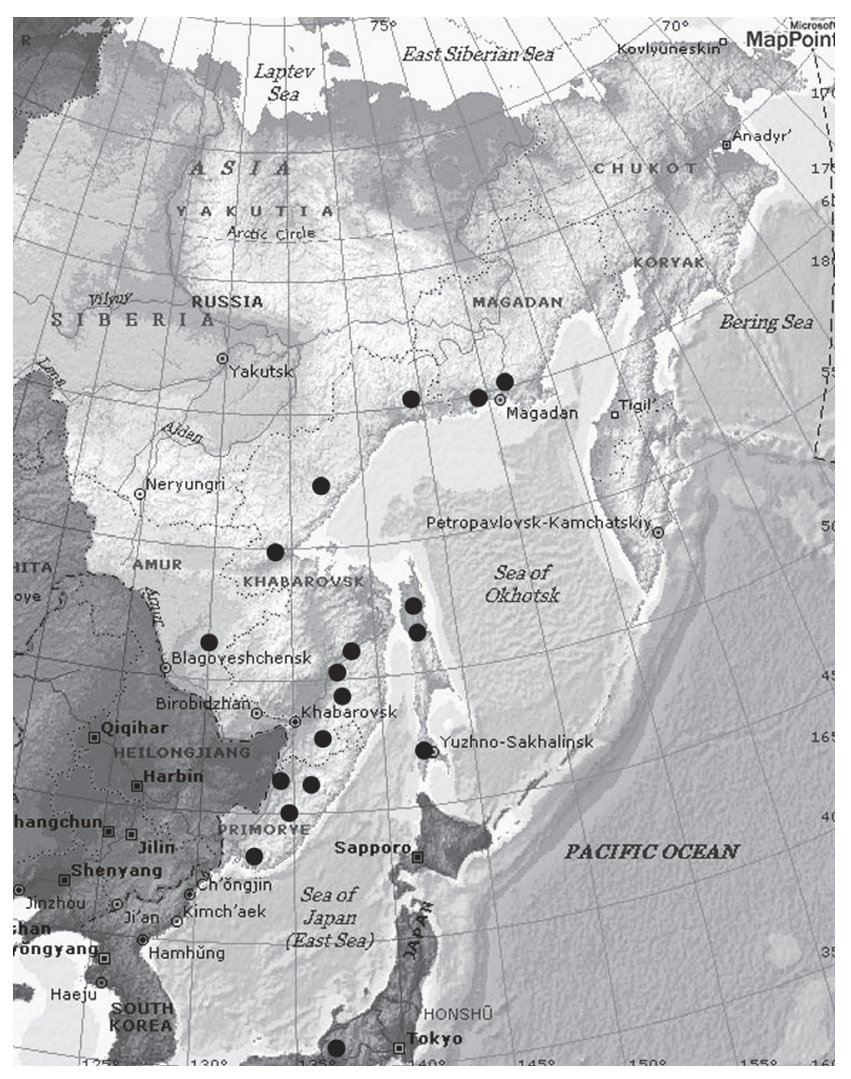

Fig. 4 Distribution of Symbiocladius (s. str.) villosus sp. $\mathrm{n}$. in the Far East. Black circles denote the collecting locations. 
Table 3 Comparison of adult males of Symbiocladius (s. s.) villosus sp. n. from different regions in the Far East.

\begin{tabular}{|c|c|c|c|c|}
\hline Characters & Bol. Ussurka River ( $n=3$ ) & Gur River $(n=1)$ & $\begin{array}{l}\text { Rivers: Ljutoga, Bureya } \\
\text { Anjui, Niman }(n=4)\end{array}$ & Japan $(n=2)$ \\
\hline Total length, mm & $4.2-4.5$ & 4.1 & $3.2-4.0$ & $3.0-3.2$ \\
\hline Wing length, mm & $3.0-3.12$ & 2.52 & $2.08-2.84$ & $2.44-2.48$ \\
\hline$A R$ & $1.23-1.38$ & 1.12 & $1.34-2.17$ & 1.17 \\
\hline Palpomeres 1-3 length, $\mu \mathrm{m}$ & $76-84: 80-108: 96-100$ & $68: 76: 76$ & $48-72: 52-116: 40-76$ & $68: 68: 60$ \\
\hline Postorbitals & $0-3$ & $6-7$ & $0-3$ & 0 \\
\hline Dorsocentrals & $4-14$ & 12 & $5-7$ & $5-6$ \\
\hline Prealars & $5-10$ & 7 & $5-7$ & 4 \\
\hline Scutellars & 0 & 0 & $0-3$ & 0 \\
\hline $\mathrm{LR}_{1}$ & $0.72-0.76$ & 0.69 & $0.70-0.71$ & $0.60-0.65$ \\
\hline $\mathrm{LR}_{2}$ & $0.49-0.53$ & 0.48 & $0.49-0.51$ & $0.46-0.50$ \\
\hline $\mathrm{LR}_{3}$ & $0.55-0.59$ & 0.54 & $0.48-0.51$ & $0.46-0.50$ \\
\hline Number of spurs on hind tibia & $1-2$ & 2 & $1-2$ & 2 \\
\hline Gonocoxite length, $\mu \mathrm{m}$ & $364-380$ & 324 & $244-320$ & 312 \\
\hline Gonostylus length, $\mu \mathrm{m}$ & 180 & 160 & $128-148$ & 140 \\
\hline Number of megasetae & $1-2$ & 2 & 2 & 2 \\
\hline $\mathrm{HR}$ & $2.02-2.11$ & 2.0 & $1.90-2.16$ & 2.22 \\
\hline HV & $2.33-2.50$ & 2.56 & $2.35-2.7$ & $2.14-2.28$ \\
\hline
\end{tabular}

Adult males from different regions in the Far East are slightly different from each other. For example, specimens from Bol. Ussurka River have the greatest body lengths $(4.2-4.5 \mathrm{~mm})$, whereas the smallest males (3.0-3.2 mm length) were registered from Japan. Variation in other features is shown in Table 3.

\section{Distribution and biology}

S. (s. s.) villosus sp.n. is known from many regions of the Russian Far East and from Japan (Fig. 4). All mayfly nymphs from which larvae and pupae of $S$. (s. s.) villosus sp. $\mathrm{n}$. were collected belong to the family Heptageniidae (Table 1).

\section{Acknowledgements}

We are grateful to Dr. Tadashi Kobayashi for making material from Japan available to us. Also we are much indebted to Dr. Wojciech Giłka for material of Symbiocladius (s. s.) rhithrogenae from Ukraine. We also wish to acknowledge Dr. Martin Spies for sending us copies of hardto-reach taxonomic articles and for editing of manuscript.

\section{REFERENCES}

Andersen T, Sæther OA, Cranston PS, Epler JH (2013) The larvae of Orthocladiinae (Diptera: Chironomidae) of the Holarctic Region - Keys and diagnoses. Insect Syst Evol Suppl 66: 189-385.

Ashe P, O'Connor JP (2012) A World Catalogue of Chironomidae (Diptera) Part 2. Orthocladiinae. Irish Biogeographical Society and National Museum of Ireland, Dublin.
Bengtsson S (1909) Beiträge zur Kenntnis der westpaläarktischen Ephemeriden. Lunds Univ Arsbok (N.F.) Afd 2, 5: 237-246.

Brodsky KA (1930) Contributions to the fauna of Ephemeroptera of Southern Siberia. Entomologicheskoe Obozrenie 24: 31-40, in Russian.

Caldwell BA (1984) Two new species and records of other chironomids from Georgia (Diptera: Chironomidae) with some observations on ecology. Georgia J Sci 42: 81-96.

Claassen PW (1922) The larva of a chironomid (Trissocladius equitans n.sp.) which is parasitic upon a may-fly nymph (Rhithrogena sp.). Kansas Univ Sci Bull 14: 395-399.

Coffman WP, Cranston PS, Oliver DR, Sæther OA (1986) The pupae of Orthocladiinae (Diptera, Chironomidae) of the Holarctic region - Keys and diagnoses. Entomol Scand Suppl 28: 147-296.

Cranston PS, Oliver DR, Sæther OA (1983) The larvae of Orthocladiinae (Diptera, Chironomidae) of the Holarctic Region Keys and diagnoses. Entomol Scand Suppl 19: 1-51.

Cranston PS, Oliver DR, Sæther OA (1989) The adult males of Orthocladiinae (Diptera, Chironomidae) of the Holarctic region Keys and diagnoses. Entomol Scand Suppl 34: 165-352.

Giłka W, Kłonowska-Olejnik M, Godunko R J (2007) On the biology of Symbiocladius rhithrogenae (Zavřel, 1924) (Diptera: Chironomidae) from the Chornohora Mts., Ukraine. Polish J Entomol 76: 285-291.

Hayashi F, Kobayashi T (2000) Commensal and parasitic chironomids of Japan. Hyogo Freshwater Biol 51/52: 281-303.

Kluge NYu (1980) To the knowledge of mayflies (Ephemeroptera) of Taimyr National District. Entomologicheskoe Obozrenie 59: 561-579, in Russian.

Kluge NYu (1995) A catalogue of the type-specimens in the collection of the Zoological Institute, Russian Academy of Sciences. Insecta, Ephemeroptera. St. Petersburg, Zoological Institute Rus Acad Sci: 1-52, in Russian.

Makarchenko EA (1985) Chironomids of the Soviet Far East. Subfamilies Podonominae, Diamesinae and Prodiamesinae (Diptera, Chironomidae). DVNC AN SSSR Press, Vladivostok, in Russian. 
Makarchenko EA, Makachenko MA (2006) Subfamily Orthocladiinae. In: Lelej A (ed) Key to the insects of Russian Far East. Vol. 6. Diptera and Siphonaptera. Pt 4. Vladivostok, Dal'nauka, pp. 280-372, 482-530, 623-671, in Russian.

McDunnough J (1933) The nymph of Cinygma integrum and description of a new heptagenine genus. Can Entomol 65: 73-76.

Rostock M (1878) Die Ephemeriden und Psociden Sachsens mit Berucksichtigung der meisten ubrigen deutschen Arten. Jahresb D. Ver. F. Naturk. Zwickau 1877: 76-100.

Sæther OA (1980) Glossary of chironomid morphology terminology (Diptera, Chironomidae). Entomol Scand Suppl 14: 1-51.
Sæther OA, Spies M (2013) Fauna Europaea: Chironomidae. In: Beuk P, Pape T (eds) Fauna Europaea: Diptera Nematocera. Fauna Europaea version 2.6. http://www.faunaeur.org.

Schmid PE (1993) A key to the larval Chironomidae and their instars from Austrian Danube region streams and rivers with particular reference to a numerical taxonomic approach. Part I. Diamesinae, Prodiamesinae and Orthocladiinae. Wass Abwass Suppl 3/93: 1-514.

Ueno M (1928) Some Japanese mayfly nymphs. Memoirs of the College of Science, Kyoto Imperial University (Ser. B) 4: 19-63. 